\title{
The influences of audit fees, competence, independence, auditor ethics, and time budget pressure on audit quality
}

\author{
Neni Meidawati*, Arden Assidiqi \\ Accounting Department, Universitas Islam Indonesia, Yogyakarta, Indonesia \\ ${ }^{*}$ Corresponding author email: neni.meidawati@uii.ac.id
}

A R T I C LE I N F O

Article history:

Available online

Keywords:

Audit fee, competence, auditor

ethics, time budget pressure

DOI:

https://doi.org/10.20885/jaai.vol23. iss2.art6
A B S T R A C T

This study aims to determine the effects of audit fees, auditor's competence, independence, and ethics, as well as time budget pressure on audit quality. This research used quantitative method. The population was the auditors who worked in Accounting Firms in Semarang City, Indonesia. The sampling technique was simple random sampling with 45 respondents. The data were collected by distributing the questionnaires to several auditors working at the accounting firms. The data were analyzed using multiple regression analysis. The results of this study indicate that the competence, auditor ethics, and time budget pressure had positive effect toward audit quality. Meanwhile, audit fee negatively affected audit quality, and independence had no effect on audit quality.

\section{Introduction}

A user of financial statements will always look for the information about the reliability of a company's financial statements (Tayib et al., 1999). To be reliable and accurate, the information of financial statements must be audited independently. As a result, the information can be used as a basis to make a complete, accurate, and unbias decision. The extant literature has also documented the role of audit committees in reducing internal control weakness and financial statement restatement frequency, and increasing earnings quality (Abbott et al., 2003; Zhou et al., 2018).

Without using independent auditor service, a company management cannot ensure the third party that its financial statements contain accountable information since from the third party's point of view, the management must always have either financial interest or other types of interest. Therefore, the management commonly requires the auditor to guarantee the users of the financial statements that the financial statements are accountable (Ardini, 2010). The community expects a clean and independent assessment on the information presented by a company management in its financial statements (Mulyadi, 2002).

The quality of auditing becomes the focus due to the violations conducted by the Public Accountants which impacted a number of Public Accounting Firms which resulted in their license suspension by Ministry of Finance. The cases indicated that the auditors had violated Standar Profesional Akuntan Publik (SPAP). Therefore, the audit quality is very crucial since high quality audit will generate virtuous financial statements as the basis for decision making.

Position and attitude of independent internal auditor, high level of information disclosure, and high obedience in financial reporting can be viewed from given auditor opinion (Sunaryo et al., 2019). Benchmarks or parameters of an auditor, which can be said to be independent and competent, are influenced by several factors including audit fee, time budget pressure competence, independence, and auditor ethics. Audit fee is a cooperation contract between auditor and client which determines the amount of fee, as well as the ethic implemented during the auditing performance which can influence the quality of audit. Time budget pressure is a situation when an auditor is required to apply efficiency over the time budget that has been arranged or when there is a strict budget time limit (Sososutikno, 2003). DeFond and Zhang (2014) view the audit-client contract environment as an important input into the audit process and thus see audit fees as a key aspect of the auditclient contract environment. It is said that audit costs are a useful proxy for audit quality because they are expected to measure the level of auditor effort, which is an input to the audit process that is intuitively related to audit quality (DeFond \& Zhang, 2014; Ghafran \& O'Sullivan, 2017) 
Hence, time budget pressure is strongly related to the time limit which may arise or happen during the assignment that makes an auditor leave the important parts of auditing program which can decrease the audit quality. Another factor to improve the audit quality is the competence level of an auditor in doing an audit in addition to professional ethics and independence in which the auditor does not have the same interests as that of the client.

The research on the factors influencing the audit quality has been conducted with variety of findings. Arisinta (2013), Tarigan et al. (2013), and Chrisdinawidanty et al. (2016) conducted the research on the influences of audit fee, competence, and independence on audit quality which revealed the evidence that audit fee positively influenced audit quality. However, Siregar et al. (2011) found out that audit fee negatively influenced audit quality. Other research also supported that audit fee had no influence on audit quality. Arisinta (2013), Shintya et al. (2016), and Putri et al. (2015) argued that competence had positive impact on audit quality. Ardini (2010) and Tjun et al. (2012) also stated that competence influenced audit quality. In contrast, Tarigan et al. (2013) contradicted the results and proved that competence had no influence audit quality. Meanwhile, according to Arisinta (2013), Shintya et al. (2016), and Putri et al. (2015) independence also positively influences audit quality, which is supported by Ardini (2010) who urged that independence influenced audit quality. Nonetheless, Tjun et al. (2012) claimed that independence did not influence audit quality.

The ethics of auditor positively impact audit quality according to the results of reseach performed by Tarigan et al. (2013) and Chrisdinawidanty et al. (2016). Also, Arisinta (2013) and Shintya et al. (2016) obtained evidence that time budget pressure positively impact audit quality. Those large varieties of research findings encourage the researchers to examine the factors which are suspected to possibly influence audit quality. The factors to be investigated include audit fee, competence, independence, auditor ethics, and time budget pressure. The respondents were the auditors working in Public Accounting Firms in the areas of Semarang City. The reason behind the sampling was the facts that in 2008 Ministry of Finance suspended a number of Public Accounting Firms in Semarang due to the violations of auditing standards which decreased the audit quality.

\section{Literature Review}

\section{Contracting Theory}

Contracting Theory according to Scott (2012) is used to explain that accounting firm comprises of a group of contracts among varieties of interests, including partnership contracts with clients, junior auditors, employees of accounting firm, government, and other related parties. Contracting Theory shows the existence of binding between auditor and client as an agent (management). Auditor as an independent third party is needed to supervise the work performance of management whether it has acted in accordance with the principal's interests through the financial statements. Auditor tasks are giving the opinion on the accountability of a company's financial statements and revealing the going concern faced by the company in case the auditor doubts the company survivability (Shintya et al., 2016).

Auditor has the interest to defend his/her opinion since high audit fee is made to generate high quality audit. Auditor can also be in a problematic situation if there is a conflict of interests with his/her agent which usually starts from structural mechanism between the auditor and management. Management appoints an auditor to conduct an audit for its principle interests; on the other side, management also pays the auditor. This creates a dependence of the auditor on the client for the sake of long cooperation to realize close relationship between auditor and client. Consequently, to maintain auditor independence, there should be a compulsory audit rotation (Hayes et al., 2017).

\section{Moral Development Theory}

The theory was developed by Kohlberg (1958) by investigating the process of moral decision along with increasing age. This research was initiated by Piaget (1932) who stated that logic and morality developed through constructive stages. This theory believes that moral reasoning was a basis of ethical behavior. Ethical behavior is a behavior that is in line with the generally accepted social norms and related to beneficial and harmful actions. Ethical behavior is also defined as the implementation of fair actions complying with the prevailing constitutional laws and government regulations. The ethical behavior pattern of an individual develops from time to time, so each individual shows perpetual changes on his/her ethical behavior. The behavior is influenced by personal experience, organization, organizational environment, and public society. Ethical behavior of an individual often refers to the individual belief. Theory of Moral Development can influence an auditor to be honest, fair, strict, and 
free from the pressures and requests of other parties or individual interests which may keep the auditor from making qualified decision (Chrisdinawidanty et al., 2016).

\section{Hope Theory}

Hope Theory predicts that an auditor will exert oneself if the auditor feels the strong relationship between effort and performance, performance and reward, as well as reward and fulfillment of personal purposes. Every of those relations is influenced by particular factors. In order to show good performance, an individual must possess the required abilities, and the performance evaluation system must be fair, neutral, and objective. The performancereward relation will be strong if the individual thinks that what is rewarded is his/her performance (Robbins \& Judge, 2013).

Hope Theory explains that motivation relies on two things, namely how strong we want something, and how likely we will get that thing (Griffin, 2012). Hope Theory is based on four basic assumptions: 1) Behavior is determined by the combination of internal and external factors; 2) An individual makes his/her own decision on his/her behavior in an organization; 3) Different individual has different types of needs, desires, and purposes; and 4) An individual selects a behavior out of various alternatives of behaviors based on his/her perception on how likely one particular behavior will result in a desirable purpose (Suprianto, 2009).

In regard with Hope Theory, the motivation of an auditor is to complete the audit task on time. When the auditor faces a difficult situation that it is impossible to finish the audit task punctually, the auditor might behave as he/she wants even though it violates the auditing procedure. The behavior is motivated by self defense to reach good performance (Suprianto, 2009)

\section{Audit Quality}

The two main streams of research that define audit quality are based on; first, audit attributes and the audit process, and second, auditor attributes and overall evaluation of results. The previous flow was based on the auditor's effort during the audit process and the auditor's ability to detect possible material misstatements in the financial statements (Dechow et al., 2011; Knechel et al., 2013; Laitinen \& Laitinen, 2015). SPAP states that an audit can be categorized into qualified one if it fulfills the auditing requirements or standard and quality control standard. The auditing standard is always be auditor's reference in implementing their professional responsibility on auditing the financial statements. The auditor quality is the individual professional ability of every auditor to implement his/her job.

The financial statements which are eligible for decision making is the financial statements which meet the relevant criteria and reliability. The users of the financial statements are more assured about the quality of financial statements of a company if the financial statements have already been audited and comply with those two criteria (Halim, 2015). The point of view of public accountant profession indicates that an audit is an objective examination on financial statements of a company or an organization to prove that the financial statements are presented properly, in all material things, financial position, and business revenue of the company or organization (Mulyadi, 2002). An auditor must own sufficient audit quality to reduce the disharmony between management and shareholders because the users of the financial statements, especially shareholders, will make a decision based on the audited financial statements (Shintya et al., 2016)

\section{Audit Fees}

Halim (2015) stated that audit fee is another important thing to consider in an assignment of an auditor. An auditor works to earn decent income; thus, the audit fee must be agreed by both client and auditor. There are three bases to determine the audit fee of an auditor, namely per diem, flat or contract, and maximum fee. The amount of audit fee depends on several factors, those are financial characteristics, such as income rate, asset profit, capital, etc.; environment, like competition, professional staff market, etc.; operation characteristics, including type of industry, number of company locations, number of product lines, etc.; and, auditor external activities, including experience, level of coordination with the internal auditor, etc.

Higher audit fees may indicate greater audit efforts and may also represent additional risk premiums imposed by auditors to counter the possibility of increasing financial obligations arising from the audit (Bell et al., 2008; Ghafran \& O'Sullivan, 2017; Seetharaman et al., 2002). In addition, variations in audit fees can also reflect changes in auditor efficiency. Finally, audit fees capture the supply and demand factors (Ghafran \& O'Sullivan, 
2017). As a result, as highlighted by DeFond and Zhang (2014), researchers must be careful in interpreting the results of the audit fee study as an increase in audit costs cannot be clearly interpreted as improving audit quality.

\section{Competence}

The audit standard mentions that an audit must be conducted by an individual or more who have reserved the necessary expertise and participated in technical trainings as auditor. It also mentions that in the audit implementation and report making process, an auditor is obliged to apply his/her professional expertise precisely and thoroughly (Halim, 2015). The audit standard demands technical competence of an auditor who conducts an audit. This competence is determined by three factors: formal education in accounting study program of a university, including professional test of auditor; practical training and experience in auditing; and sustainable professional education during a career as a professional auditor. Shintya et al. (2016) argued that auditor competence itself was a competence owned by an auditor to perform an audit by applying broad knowledge and special expertise. The competence is obtained through education and experience. Each auditor must strive to reach high level of professionalism as implied in Principle of Ethics during his/her task and responsibility implementation.

\section{Independence}

Halim (2015) assumed that an auditor must be independent or free from any influence of the client in auditing, reporting findings, and giving opinion. An auditor must not give opinion on the properness of financial statements if he/she is not independent from his/her client. There are three types of independence, including infact independence, independence in appearance, and independence in competence. Independence does not only involve an individual auditor, but also all auditors together in the profession which include 1) Practitioner independence, which is a perception, impartial attitude, and confidence that can affect the auditor approach during an examination. 2)Profession independence, which is a perception of the members of financial/business society on accountant profession as a group. Shintya et al. (2016) said that independence can be described as a perspective which is unbiased in doing examination, evaluation of findings, and reporting the result.

\section{Audit Ethics}

Tarigan et al. (2013) defined ethic as the critical attitude of each individual or group of society in relaizing morality, and ethic suggested people to behave accordance to morality. Moral and ethic have the same function namely to give orientation in how and where to go in one's life. Morality serves as a concrete regulation or direction for human on how to live and to act in life as a human who is well behave and to avoid bad behavior; ethic is values and moral norms which determine human behavior in life. Organisation for Economic Cooperation and Development (OECD) (2004) stated that in a number of companies either the audit committee or an ethics committee is specified as the contact point for employees who wish to report concerns about unethical or illegal behaviour that might also compromise the integrity of financial statements.

Halim (2015) suggested that auditor ethic is the moral principles to be used as a guidance in auditing to generate high quality audit. The profession of public accountant puts attention on quality as the most important thing to ensure the auditor profession can fulfill the obligation to the client. Professional ethic includes attitude standard for the member of the profession which is practical and realistic, but also idealistic. The demands of professional ethics must be over the laws but below the ideal standards ethics (absolute) so the ethics have meaning and duly prevail. The indicators in measuring ethics according to Chrisdinawidanty et al. (2016) are professional responsibility, public interest, integrity, objectivity, competence and professional prudence, professional behavior, and technical standard.

\section{Time Budget Pressure}

Shintya et al. (2016) stated that time budget pressure is a condition where an auditor is demanded to apply an efficiency on the designed time budget or to impose strict time budget deadline. Auditor often works on the deadline; therefore, every accounting firm needs to design time budget in every audit activity. When facing time budget pressure, according to (DeZoort \& Lord, 1997), an auditor will respond to either of these two ways: 1) Functional - an auditor behavior to work better and use time well, and 2) Dysfunctional - an auditor behavior which decreases the auditor quality. 


\section{Hypothesis}

\section{Influence of audit fee on audit quality}

Agoes (2017) assumed that audit fee was a reward in form of money or goods or other which is given to or accepted from client or other party to establish an engagement with the client or other party. According to Contracting Theory, a contract aims at explaining how the parties involved in the agreement must design the contract and determine the pricing in order to be able to attain good quality (Kurniasih \& Rohman, 2014).

Chrisdinawidanty et al. (2016) argued that when the audit fee or audit incentive increased, audit quality might also increase since the audit procedure to be conducted by the audit would be more detailed. Thus, the audit result would be more accurate and accountable. The research conducted by Chrisdinawidanty et al. (2016) showed that audit fee positively and significantly influenced audit quality.

A study performed by Arisinta (2013) and Tarigan et al. (2013) revealed that audit fee positively influenced audit quality. This means that higher audit fee will generate more qualified audit. Based on the theory and previous studies, the hypothesis is formulated as follows.

H1: Audit fee positively influences audit quality.

\section{Influence of competence on audit quality}

Mulyadi (2002) stated that competence showed attainment and maintenance of one particular level of knowledge and comprehension which enabled a member to provide services with ease ingenuity. Hope Theory indicates that in order an attempt produces good performance or quality, an individual must have the required ability to work (Robbins \& Judge, 2013).

Putri et al. (2015) pointed out the importance of competence owned by an auditor. An audit must be conducted by an individual with relevant expertise and adequate technical training as an auditor. Hence, high education level of an auditor will affect the breadth of knowledge he/she has. In addition, more experiences will enable an auditor to easily detect the falsehood in auditing. Therefore, the auditor competence which can be seen from knowledge and experience can influence the audit quality.

Ardini (2010) and Tjun et al. (2012) stated that competence affected audit quality. The research is supported by Arisinta (2013), Putri et al. (2015) and Shintya et al. (2016) who said that auditor competence positively influenced audit quality. Thus, the higher the competence level of an auditor, the better the quality of audit. Based on the theory and preceding studies, the hypothesis generated is as follows.

$\mathrm{H} 2$ : Competence positively influences audit quality.

\section{Influence of independence on audit quality}

Independence means a mental attitude which is free from influences, other party's control, and reliance on others. Independence also involves the honesty of an auditor (Mulyadi, 2002). Hope Theory explains in order to get a qualified performance in the performance assessment system, an individual must be viewed as fair and objective (Robbins \& Judge, 2013).

Ardini (2010) said that being independent meant that a public accountant was not easy to be influenced by others because he/she is doing work for public interest. Public accountant must not take side. An auditor is obliged to be honest and fair not only to the management and corporate owners, but also to the creditors and other parties who put their trust in the auditor. Losing independence will degrade the quality of audit which might make the audit report different from the reality and raise hesitation in decision making. A study conducted by Ardini (2010) proved that auditor independence influenced audit quality.

The research carried out by Arisinta (2013), Putri et al. (2015) and Shintya et al. (2016) claimed that independence positively affected audit quality. Therefore, the higher the level of auditor independence, the more qualified the audit will be. In regard with the theory and previous studies, the hypothesis is formulated as follows. H3: Independence positively influences audit quality.

\section{Influence of ethics on audit quality}

Each profession without exception puts great attention on the quality of the service catered. Public Accounting profession considers that audit quality produced is a very important to ensure the auditor profession can meet his/her obligation to his/her service users. One of the factors which is influential for audit quality is auditor compliance in code of ethics which is reflected from independence, objectivity, and many more (Halim, 2015). Ethical behavior pattern of each individual (including auditor) develops from time to time. The ethical behavior of 
an individual often refers to what he/she believes. Moral Development Theory can influence an auditor to act honestly, fairly, strictly without any pressure or request from other particular party or personal interest which later can result in making quality decision (Chrisdinawidanty et al., 2016).

The research conducted by Tarigan et al. (2013) and Chrisdinawidanty et al. (2016) showed that auditor ethics positively contributed to audit quality where the better the ethics of an auditor, the better the quality of an audit. Based on the theory and previous studies, the hypothesis is composed as follows.

H4: Auditor ethics positively influence audit quality.

\section{Influence of time budget pressure on audit quality}

According to DeZoort and Lord (1997), time budget pressure is related to time constraint which occurs or appears in audit assignment which results from (time) resource limitation which can be allocated to perform the audit. In regard with Hope Theory, auditor motivation is to complete the audit assignment on time. When the auditor faces a difficult situation when it is not possible for him/her to complete the task in the given time, the auditor tends to do an act which he/she wants though violating the audit procedure (Suprianto, 2009).

Arisinta (2013) mentioned that time budget pressure could affect the performance of an auditor in decision making and audit procedure implementation. Its positive effect was that it could stimulate the auditor motivation to finish his/her job in time.

The study carried out by Arisinta (2013) and Shintya et al. (2016) demonstrated that time budget pressure positively affected audit quality. This indicates that the better time budget pressure which an auditor has, the better the quality of his/her auditing work. In accordance with the theory and prior studies, the hypothesis is devised as follows.

H5: Time budget pressure positively influences audit quality.

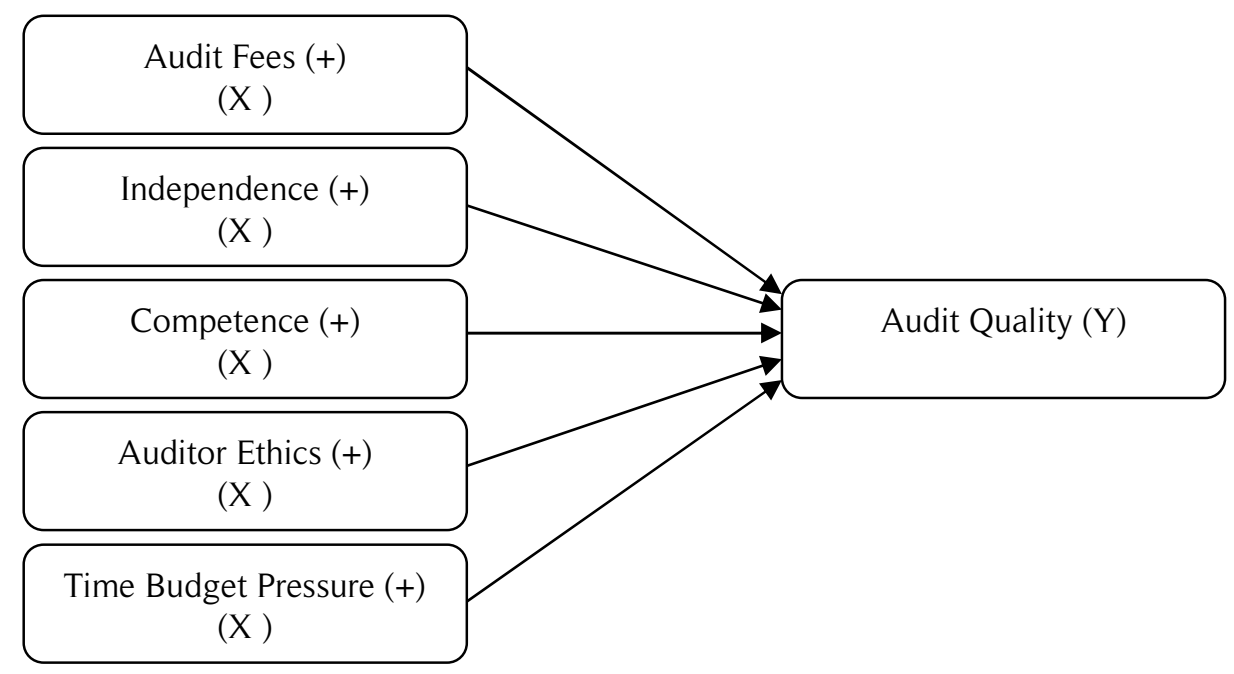

Figure 1. Research Framework

\section{Research Method}

\section{Population and Sample}

The population of this research was all auditors working in Public Accounting Firms in Semarang City. The sampling techniques used was simple random sampling (Mas'Ud, 2004). The sample size was determined using which was excerpted from Sujarweni (2014) as follows.

$$
n=\frac{\mathrm{N}}{1+N e^{2}}
$$

where:

$\mathrm{n}$ = sample size

$\mathrm{N}$ = population size as many as 100 auditors at accounting firms

e $=$ expected critical value (accuracy limit) (percentage of inaccuracy due to population sampling error). 
The researchers took e value as much as $10 \%$. Then, based on the formulation above, it will be obtained:

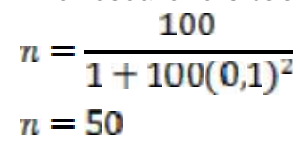

Based on the calculation above, the number of samples used in this study was 50 auditor respondents of accounting firm at Semarang city.

\section{Variable Definition and Measurement}

The variables of this research were grouped into two categories, dependent variable and independent variable. Below are the definitions and measurement of the variables of this research.

Table 1. Operational Definition and Variable Measurement

\begin{tabular}{|c|c|c|}
\hline Variable & Definition & Indicators \\
\hline $\begin{array}{l}\text { Dependent variable: } \\
\text { Audit quality }\end{array}$ & $\begin{array}{l}\text { Audit quality is an important factor to be } \\
\text { upheld by an auditor in the auditing process. } \\
\text { Audit quality is an external auditor capacity to } \\
\text { detect material errors and other forms of } \\
\text { deviations. Audit quality is a guarantee to } \\
\text { compare between the real condition and the } \\
\text { ideal condition (Putri et al., 2015). }\end{array}$ & $\begin{array}{l}\text { Conformity between examination and audit } \\
\text { standard }\end{array}$ \\
\hline $\begin{array}{l}\text { Independent variables: } \\
\text { Audit fee }\end{array}$ & $\begin{array}{l}\text { Audit fee is the payment received by an } \\
\text { auditor for doing an assignment based on } \\
\text { some considerations (Halim, 2015). }\end{array}$ & $\begin{array}{l}\text { Assignment risks } \\
\text { Assigned auditing task } \\
\text { Expertise level shown during the assignment } \\
\text { Cost structure of the related accounting firm }\end{array}$ \\
\hline Competence & $\begin{array}{l}\text { Competence can be attained through } \\
\text { education and experience. Competence is able } \\
\text { to convince the users that the audit service } \\
\text { quality provided by an auditor can meet the } \\
\text { high level of professionalism. In doing an } \\
\text { auditing process, a public accountant must act } \\
\text { as an expert in accounting and auditing. Thus, } \\
\text { auditor competence includes all knowledge } \\
\text { and experience of an auditor which are } \\
\text { adequate and explicit to conduct objective, } \\
\text { accurate, and thorough (Shintya et al., 2016). }\end{array}$ & $\begin{array}{l}\text { Knowledge } \\
\text { Experience }\end{array}$ \\
\hline Independence & $\begin{array}{l}\text { Independence is a mental attitude which is } \\
\text { free of influences, others' control, and reliance } \\
\text { on others side (Mulyadi, 2002). }\end{array}$ & $\begin{array}{l}\text { Length of relation with the client } \\
\text { Client's pressure } \\
\text { Auditor partner investigation } \\
\text { Non-audit services }\end{array}$ \\
\hline Auditor ethics & $\begin{array}{l}\text { By venerating the professional ethics, it is } \\
\text { expected that there will be no fraudulence } \\
\text { among the auditors in order to give relevant } \\
\text { audit review as expected by the corporation. } \\
\text { The higher the level of auditor ethics, the } \\
\text { better the audit quality (Chrisdinawidanty et } \\
\text { al., 2016). }\end{array}$ & $\begin{array}{l}\text { Professional responsibility } \\
\text { Public interest } \\
\text { Integrity } \\
\text { Objectivity } \\
\text { Competence and professional prudence } \\
\text { Confidentiality } \\
\text { Professional behavior } \\
\text { Conformity with technical standard }\end{array}$ \\
\hline Time budget pressure & $\begin{array}{l}\text { Time pressure suffered by an auditor in doing } \\
\text { audit will also affect the audit quality. High } \\
\text { time pressure in auditing makes an auditor } \\
\text { improve the efficiency of audit. The auditor is } \\
\text { demanded to be able to complete his/her job } \\
\text { on time as the dateline agreed with the client } \\
\text { (Shintya et al., 2016). }\end{array}$ & $\begin{array}{l}\text { Completing the audit procedure with the time } \\
\text { budget as responsibility } \\
\text { Completing the audit procedure with the time } \\
\text { budget as obstacle }\end{array}$ \\
\hline
\end{tabular}


The model of double linear regression analysis used was as follows.

$\mathrm{Y}=\alpha+\beta 1 \mathrm{X} 1+\beta 2 \mathrm{X} 2+\beta 3 \mathrm{X} 3+\beta 4 \mathrm{X} 4+\beta 5 \mathrm{X} 5+\mathrm{e}$

\section{Where:}

$\begin{array}{ll}Y & : \text { Audit quality } \\ \alpha & : \text { Constant } \\ X_{1} & \text { : Audit fee } \\ X_{2} & \text { : Independence } \\ X_{3} & \text { : Competence } \\ X_{4} & \text { : Auditor ethics } \\ X_{5} & \text { : Time budget pressure } \\ \beta_{123} & \text { : Regression coefficient } \\ \mathrm{e} & \text { : Standard error }\end{array}$

\section{Results and Discussion}

Data collection techniques used in this study were to use a questionnaire. With respondents namely public accountants who live in the Semarang, Indonesia. The questionnaire returned and completed by the respondent will then be examined for its completeness. Questionnaires were distributed as many as 50 questionnaires, but those collected by researchers were 45 respondents.

Table 2 shows the demography characteristics of participants including gender, education, age, work experience, and positions. Participants consisted of 19 males and 26 females with the age of majority is 26-35 years old. The highest level of education is bachelor degree, most length of work is 1-5 years and most of the positions are junior auditors.

Table 2. Demography Characteristics of Participants

\begin{tabular}{|c|c|c|c|}
\hline \multicolumn{2}{|c|}{ Demography Characterictis } & \multirow{2}{*}{$\begin{array}{c}\text { Number of Participants } \\
19\end{array}$} & \multirow{2}{*}{$\frac{\text { Percentage }(\%)}{42 \%}$} \\
\hline & Male & & \\
\hline Gender & Female & 26 & $58 \%$ \\
\hline \multirow{4}{*}{ Age } & 25 years & 12 & $27 \%$ \\
\hline & $26-35$ years & 22 & $49 \%$ \\
\hline & $36-45$ years & 11 & $24 \%$ \\
\hline & Diploma Degree & 9 & $20 \%$ \\
\hline \multirow{2}{*}{ Education } & Bachelor Degree & 33 & $73 \%$ \\
\hline & Master Degree & 3 & $7 \%$ \\
\hline \multirow{2}{*}{ Work experience } & $1-5$ years & 31 & $69 \%$ \\
\hline & $6-10$ years & 14 & $31 \%$ \\
\hline \multirow{2}{*}{ Positions } & Junior Auditor & 31 & $69 \%$ \\
\hline & Senior Auditor & 14 & $31 \%$ \\
\hline
\end{tabular}

Goodness of Fit model test results using $\mathrm{R}^{2}$ value is 0.499 or $49.9 \%$. It indicates that data can explain information 49.9 percent by model. The remaining $50.1 \%$ is explained by other variables (outside of model) and error. Thus, the model can be used for hypothesis testing. Hypothesis testing results using linear regression are presented in Table 3.

Table 3. Regression Results with the dependent variable of audit quality $(\mathrm{N}=45)$

\begin{tabular}{llll}
\hline Variable & B & Sig. & Result \\
\hline C & 2.905 & 0.41 & \\
Audit fee (X1) & -0.363 & 0.025 & Not supported \\
Competence (X2) & 0.307 & 0.028 & Supported \\
Independence (X3) & 0.147 & 0.215 & Not supported \\
Auditor ethics (X4) & 0.093 & 0.02 & Supported \\
Time budget pressure (X5) & 0.366 & 0.002 & Supported \\
R Square & 0.556 & & \\
Adjusted R Square & 0.499 & & \\
\hline
\end{tabular}

$Y=2.905-0.363 X 1+0.307 X 2+0.147 X 3+0.093 X 4+0.366 X 5+e$ 


\section{Audit Fees on Audit Quality}

This research findings have proven that audit fee negatively influenced audit quality, therefore the first hypothesis of this research is not supported. Agoes (2017) stated that audit fee was a reward in form of money or goods or in other forms given to or received from client or other party to create an engagement with client or other party.

Audit fee in this research negatively influenced audit quality which means that the higher the audit fee, the wider procedure of audit will be conducted by an auditor, but it does not guarantee that the audit result is reliable and accurate. It does not convince that the audit quality will be improved as well. That may happen if an auditor received higher audit fee than normal rate which can lead the auditor to be more tolerant to the actions perpetrated by his/her client. In his/her assignment, an auditor may face high risk, so he/she will receive higher fee than normal rate. This indicates that in contract there is a compromise between auditor and client which degrades the quality of audit.

Siregar et al. (2011) argued that higher audit fee was an indicator of compromise between an auditor and his/her client. This research finding was in line with the work of Siregar et al. (2011) that audit fee negatively influenced audit quality. However, the finding does not agree with the study conducted by Arisinta (2013), Tarigan et al. (2013), and Chrisdinawidanty et al. (2016).

\section{Competence on Audit Quality}

The second hypothesis suggests that competence positively influences audit quality. The research has revealed that competence positively influenced audit quality, the second hypothesis is supported. From the research, it can be concluded that the higher the competence of an auditor, the better the audit quality. Auditors must have a general standard of knowledge and skill in accounting to carry out his/her profession in reference to the stipulated procedures. Therefore, with the higher level of education an auditor has, the auditor's knowledge will be broader and he/she can work professionally. In addition, more experiences will make it easy for auditors to detect the occurrence of audit errors (Putri et al., 2015). Competence which is based on the knowledge and experience of an auditor will certainly influence audit quality. This research is in line with those of Ardini (2010), Tjun et al. (2012), Arisinta (2013), Putri et al. (2015), and Shintya et al. (2016). However, the research is not supported by the study conducted by Tarigan et al. (2013) which proved that competence did not influence audit quality.

\section{Independence on Audit Quality}

The third hypothesis suggests that independence positively influences audit quality. The research finding proved that independence did not affect audit quality, thus, the third hypothesis of this research is not supported. The audit quality in this research was not affected by independence variable which meant that the indicators showing the duration of relationship between auditor and client and whether or not a pressure from client exists, which are related to independence, did not contribute to audit quality. This may happen because the majority of the samples were junior auditors whose experiences were not yet adequate to be an indicator in determining audit quality.

Halim (015) said that everybody had variety of impressions on auditor independence, both positive and negative impressions. If someday they have to rely on an auditor work, the first impression achieved will be the determining impression which guides their next actions. This research finding is in line with the study carried out by (Tjun et al., 2012) which claimed that independence did not significantly influence audit quality. The finding, however, is not supported by the research by Arisinta (2013), Shintya et al. (2016), and Putri et al. (2015) which argued that independence brought positive contribution to audit quality, and as Ardini (2010) assumed that independence influenced audit quality.

\section{Auditor Ethics on Audit Quality}

The fourth hypothesis assumes that auditor ethics positively influence audit quality. The research finding got the evidence that auditor ethics positively influenced audit quality. Thus, the fourth hypothesis is supported.

From the evidence, it can be concluded that the higher the level of ethics that an auditor has, the better the quality of an audit. The high-quality product must be prioritized in each profession. Public accountant profession very concerns about audit quality as the important guarantee that an auditor can fulfill his/her obligation to his/her client. The auditor ethics will be very much influential on the audit quality and decision making because the compliance of an auditor in code of conduct and norms will be reflected in his/her integrity, objectivity, professional behavior, and many more. 
Tarigan et al. (2013) stated that a public accountant has an awareness to behave ethically which meant that he/she had commitment to apply professional public accountant code of ethics. If the commitment is preserved, the violation could be prevented, and the public accountant could improve the audit quality. Consequently, by highly respecting professional ethics, it is expected that there will be no more fraudulence among auditors so that the auditors can present audit review relevant to the financial statements. This research agrees with the study conducted by Chrisdinawidanty et al. (2016) and Tarigan et al., (2013).

\section{Time Budget Pressure on Audit Quality}

The fifth hypothesis assumes that time budget pressure positively influenced audit quality. The research gave evidence that time budget pressure positively influenced audit quality. Hence, the fifth hypothesis is supported. Time budget pressure has positive contribution to audit quality which can be concluded that time budget pressure faced by auditors significantly affects audit quality. Time budget pressure is related to time constraint which appears during assignment due to the limited time. With the constraint, an auditor is motivated to complete his/her work by using time as efficient as possible to produce good quality of audit.

Arisinta (2013) stated that time budget pressure could affect the performance of an auditor in decision making and procedure implementation. With the stricter time budget pressure, an auditor was stimulated to work with enthusiasm to finish his duty. This research supports the study done by Arisinta (2013) and Shintya et al (2016).

\section{Conclusion}

First, audit fee has negative effect on the audit quality. It means the higher audit fess, the lower audit quality. Second, auditor's competence has positive effect on the audit quality. It means the higher auditor's competence, the higher audit quality. Third, auditor independence has no effect on the audit quality. It means the auditor independence does not affect the audit quality. Fourth, auditor ethics has positive effect on audit quality. It means the higher the level of ethics that an auditor has, the better the quality of an audit. Fifth, audit time budget has positive effect on audit quality. It means the time budget pressure faced by auditors significantly affects audit quality.

This research collected the data using questionnaire method which was left at the Public Accounting Firms agreed. The data filled out were then merely based on the respondents' perspectives, so the researchers could not really monitor the truth of the responses of the questionnaires returned. Besides, there was no direct interview with the respondents. Further research can conduct direct interview to the respondents to collect data. In addition, it can also test other variables which may affect audit quality.

\section{References}

Abbott, L. J., Parker, S., Petersa, G. F., \& Raghunandan, K. (2003). The association between audit committee characteristics and audit fees. Auditing: A Journal of Practice \& Theory, 22(2), 17-32.

Agoes, S. (2017). Auditing: petunjuk praktis pemeriksaan akuntan oleh akuntan publik (edisi 5). Jakarta: Salemba Empat.

Ardini, L. (2010). Pengaruh kompetensi, independensi, dan motivasi terhadap kualitas audit. Majalah Ekonomi, 20(3), 329-349. https://doi.org/10.1523/JNEUROSCI.6376-10.2011

Arisinta, O. (2013). Pengaruh kompetensi, independensi, time budget pressure, dan audit fee terhadap kualitas audit. Jurnal Ekonomi dan Bisnis Airlangga, 23(3).

Bell, T. B., Doogar, R., \& Solomon, I. (2008). Audit labor usage and fees under business risk auditing. Journal of Accounting Research, 46(4), 729-760.

Chrisdinawidanty, Z. N., Tugiman, H., \& Muslih, M. (2016). Pengaruh etika auditor dan audit fee terhadap kualitas audit (studi kasus pada kantor akuntan publik di wilayah Bandung). E-Proceeding of Management, 3(3), 3466-3474.

Dechow, P. M., Ge, W., Larson, C. R., \& Sloan, R. G. (2011). Predicting material accounting misstatements. Contemporary Accounting Research, 28(1), 17-82.

DeFond, M., \& Zhang, J. (2014). A review of archival auditing research. Journal of Accounting and Economics, 
58(2-3), 275-326.

DeZoort, F. T., \& Lord, A. T. (1997). A review and synthesis of pressure effects research in accounting. Journal of Accounting Literature, 16, 28-85.

Ghafran, C., \& O'Sullivan, N. (2017). The impact of audit committee expertise on audit quality: evidence from UK audit fees. British Accounting Review, 49(6), 578-593. https://doi.org/10.1016/j.bar.2017.09.008

Griffin, R. W. (2012). Management (11th ed.). Natorp Blvd, Mason: Cengage Learning.

Halim, A. (2015). Auditing I: dasar-dasar audit laporan keuangan. Yogyakarta: UPP STIM YKPN.

Hayes, Rick, Wallage, P., \& Gortemaker, H. (2017). Prinsip-prinsip pengauditan. Jakarta: Salemba Empat.

Knechel, W. R., Krishnan, G. V., Pevzner, M., Shefchik, L. B., \& Velury, U. K. (2013). Audit quality: Insights from the academic literature. Auditing: A Journal of Practice \& Theory, 32(1), 385-421.

Kohlberg, L. (1958). The development of modes of thinking and choices in years 10 to 16. Ph.D. Dissertation, University of Chicago.

Kurniasih, M., \& Rohman, A. (2014). Pengaruh fee audit, audit tenure, aan rotasi audit terhadap kualitas audit. Diponegoro Journal of Accounting, 3(3), 1-10.

Laitinen, E. K., \& Laitinen, T. (2015). A probability tree model of audit quality. European Journal of Operational Research, 243(2), 665-677. https://doi.org/10.1016/j.ejor.2014.12.021

Mas'Ud, F. (2004). Survai diagnosis organi sasional konsep dan aplikasi. Semarang: Badan Penerbit Universitas Diponegoro.

Mulyadi. (2002). Auditing (6th ed.). Jakarta: Salemba Empat.

Organisation for Economic Co-operation and Development. (2004). OECD principles of corporate governance. Paris. https://doi.org/10.1007/978-4-431-30920-8_10

Piaget, J. (1932). The moral judgment of the child. London: Kegan Paul, Trench, Trubner \& Co.

Putri, D. I., Nugraha, N., \& Budiyono, I. (2015). Analisis pengaruh independensi, kompetensi, dan ukuran kantor akuntan publik terhadap kualitas audit (studi kasus pada auditor kantor akuntan publik di kota Semarang). In Seminar Nasional Terapan Riset Inovatif (Sentrinov) (pp. 463-481). Semarang: Sentrinov.

Robbins, S. P., \& Judge, T. A. (2013). Organizational behaviour individuals (15th ed.). Boston: Pearson.

Scott, W. R. (2012). Financial accounting theory (6th ed.). Canada: Pearson.

Seetharaman, A., Gul, F., \& Lynn, S. G. (2002). Litigation risk and audit fees: evidence from UK firms cross-listed on US markets. Journal of Accounting and Economics, 33(1), 91-115.

Shintya, A., Nuryatno, M., \& Oktaviani, A. A. (2016). Pengaruh kompetensi, independensi, dan tekanan anggarana waktu terhadap kualitas audit. In Seminar Nasional Cendekiawan ke 2 (pp. 1-19). Jakarta: Lembaga Penelitian Universitas Trisakti University.

Siregar, S. V., Fitriany, Wibowo, A., \& Anggraita, V. (2011). Rotasi dan kualitas audit: evaluasi atas kebijakan menteri keuangan kmk No. 423/KMK.6/2002 tentang jasa akuntan publik. Jurnal Akuntansi Dan Keuangan Indonesia, 8(1), 1-20.

Sososutikno, C. (2003). Hubungan tekanan anggaran waktu dengan perilaku disfungsional serta pengaruhnya terhadap kualitas audit. In Simposium Nasional Akuntansi VI. (pp. 1-10). Surabaya: Ikatan Akuntan Indonesia Kompartemen Akuntan Pendidik (IAI KAPd).

Sujarweni, V. wiratn. (2014). Metode penelitian: lengkap, praktis, dan mudah dipahami. Yogyakarta: Pustaka Baru Press.

Sunaryo, K., Astuti, S., \& Zuhrotun. (2019). The role of risk management and good governance to detect fraud financial reporting. Journal of Contemporary Accounting, 1(1), 38-46. https://doi.org/10.20885/jca.vol1.iss1.art4

Suprianto, E. (2009). Pengaruh time budget pressure terhadap perilaku disfungsional auditor (audit quality 
reduction behaviour, premature sign-off \& under reporting of time) (studi kasus pada kantor akuntan publik di Jawa Tengah). Jurnal Akuntansi dan Investasi, 5(1), 57-65.

Tarigan, M. U., Bangun, P., \& Susanti. (2013). Pengaruh kompetensi dan independensi auditor terhadap kualitas audit. Akuntansi, 13(1), 803-832.

Tayib, M., Coombs, H. M., \& Ameen, J. R. M. (1999). Financial reporting by Malaysian local authorities. International Journal of Public Sector Management, 12(2), 103-121. https://doi.org/http://dx.doi.org/10.1108/MRR-09-2015-0216

Tjun, L. T., Marpaung, E. I., \& Setiawan, S. (2012). Pengaruh kompetensi dan independensi auditor terhadap kualitas audit. Jurnal Akuntansi, 4(1), 33-56.

Zhou, H., Owusu-Ansah, S., \& Maggina, A. (2018). Board of directors, audit committee, and firm performance: evidence from Greece. Journal of International Accounting, Auditing and Taxation, 31, 20-36. https://doi.org/10.1016/j.intaccaudtax.2018.03.002 